\title{
Research on the Sexual Minority Counseling Experience of the Counselors
}

\author{
Jeang-Nam Kim \\ Tongmyong Univ \\ nam630@tu.ac.kr
}

\begin{abstract}
The purpose of this study was to examine the experiences that counselors in Korea have experienced during counseling sexual minorities. In-depth interview was selected as the method of research, and it was analyzed based on consensual qualitative research (CQR). The selected participants were composed of ten counselors who have experienced counseling sexual minority clients. As a result, eight domains were and a total of 30 categories were created. Finally, the results of this study were discussed.
\end{abstract}

Keywords: Sexual minority, Sexual minority counseling, Sexual minority counseling experience, $C Q R$

\section{Introduction}

Lesbian, Gay, Bisexual, and Transgender (LGBT) people seek psychotherapy at higher rates than heterosexuals [12][2][9]. However, sexual minorities who seek counseling complain that they cannot get proper treatment and intervention [14][9][15].

The most severe issue among inadequate interventions during counseling is that counselors regard homosexuals or bisexuals as people with mental disorder [7] or they recommend sexual minorities not to accept their sexual orientation [13]. This attitude would lead to conversion therapy, offending sexual minorities' mind. Another inappropriate intervention includes the fact that even though client's counseling issue is not related to sexual orientation, counselors continue to counsel with the subject of sexual orientation [1]; Pachankis \& Goldfried, 2004 [13]. In addition to that, improper interventions [16] include the fact that counselors are reluctant to ${ }^{3}$ have the conversation of gender identity [13], counselors lacks understanding of sexual minorities and do not recognize discrimination or prejudice clients would face [6] and counselors suppose that clients would be heterosexuals without doubt [13][6]. These interventions additionally hurt LGBT clients who are ready to get counseling because of psychological difficulties.

If looking at counselors' improper intervention in counseling sexual minorities from a different perspective, it is related to difficulties the counselors face while counseling. They are not free from heterosexism and homophobia [5][8][16]. Therefore, the

1 This study was carried out with the support of the Korea Research Foundation. (Assignment number, NRF2017S1A5A2A01024668) This study was reviewed by the Institutional Review Board (IRB) of Tongmyung University. (TUIRB-2017-003)

248520 Dept. Counseling Psychology Science, Tongmyong Univ., 428 Sinseon-ro, Nam-gu, Busan, Republic of Korea. email: nam630@tu.ac.kr

3 Article history:

Received (May 24, 2018), Review Result (July 24, 2018), Accepted (October 23, 2018) 
counselors sometimes undergo internal conflicts between their values and professional ethical requirements for supporting sexual minority clients [4][5][11]. This conflict leads to counselors' psychological challenges, reducing therapeutic capacity. It also causes inappropriate interventions. Even though the counselors embrace their clients' gender identity, they could face challenges while counseling because of a lack of understanding of clients' specific mental issues [16].

The counselors lack the opportunity of looking back on their prejudice against sexual minorities and getting education to treat sexual minority clients [18][16]. In particular, the Graduate School of Counseling Psychology has no training course of dealing with the subject of sexual orientation in an integrated way [12][18]. Therefore, the counselors feel that they are not fully ready to counsel LGBT clients [14].

In Korea, given that training and education related to sexual minorities in the academic world of counseling psychology is an elementary level, counselors may face challenges when counseling LGBT clients. So, it is required to specifically look at the experience where counselors would undergo while counseling sexual minorities. This would help find suggestions and improvement directions necessary for educating and training not only counseling professionals who are engaging in counseling currently but also future counseling workforces.

\section{Study method}

\subsection{Study participants}

The researcher sent a mail to adjacent university counseling centers and counseling specialists, recruiting ten ones who have counseled sexual minorities.

\subsection{The method of an interview and qualitative analysis}

Recruited participants got a preliminary interview and ten counselors who were willing to open their experience and agree with the study signed a research consent form. It took 50 90 minutes to interview them while recording conversations under participants' consent and then a verbatim recording was written. Three experienced specialists on a qualitative analysis analyzed written data excluding personal information with the use of consensual qualitative research $(\mathrm{CQR})$ methodology. The concrete procedure of $\mathrm{CQR}$ methodology is as follow:

\subsection{Ethical consideration}

As this study is about sexual minorities and this subject is less generalized and sensitive, ethical considerations are deliberated as follows: Firstly, this study was conducted after passing IRB review. Secondly, study participants read a consent form regarding the purpose and ethics of this study in advance and the consent form was given to voluntary participants and then the study proceeded to the next stage.

\section{Study result}

The researcher conducted an in-depth interview among counselors in terms of counseling experience on sexual minorities. The result was analyzed with the use of CQR methodology where three researchers drew the concept, subcategories and domains through discussion and consultation. As a result, eight domains were generated and 30 
categories per each domain were created. Typical categories (over five cases that are more than half) and variant categories (2 4 cases) were divided according to how frequently each fixed category was applied out of total cases with the use of a cross analysis. One case was regarded as an exceptional one and then it was excluded from the analysis. Table 2 shows the frequency result of the domain, subcategories and domains.

Table 1. Results of crosstabs the sexual minority counseling experience

\begin{tabular}{|c|c|c|}
\hline Domain & Category & Frequency \\
\hline $\begin{array}{l}\text { 11. The process of finding } \\
\text { out that the client is sexual } \\
\text { minority }\end{array}$ & $\begin{array}{l}\text { 1) A client makes known gender identity while signing up } \\
\text { for an interview } \\
\text { 2) A client reluctantly discloses gender identity at an early } \\
\text { stage of counseling } \\
\text { 3) The gender identity of a client is exposed while } \\
\text { counseling with a different subject }\end{array}$ & $\begin{array}{l}3 \text { (Variant) } \\
2 \text { (Variant) } \\
5 \text { (Typical) }\end{array}$ \\
\hline $\begin{array}{l}\text { 2. The psychological } \\
\text { characteristics of the } \\
\text { counselor after knowing } \\
\text { that the client is sexual } \\
\text { minority }\end{array}$ & $\begin{array}{l}\text { 1) Confusion } \\
\text { 2) A lack of understanding on sexual minorities } \\
\text { 3) Burden of counseling } \\
\text { 4) Concerns over clients } \\
\text { 5) No impact on counseling }\end{array}$ & $\begin{array}{l}2 \text { (Variant) } \\
4 \text { (Variant) } \\
6 \text { (Typical) } \\
3 \text { (Variant) } \\
3 \text { (Variant) }\end{array}$ \\
\hline $\begin{array}{l}\text { 3. The impact of the } \\
\text { counselor on the counseling } \\
\text { intervention after the } \\
\text { counselor became aware } \\
\text { that the client was sexual } \\
\text { minority }\end{array}$ & $\begin{array}{l}\text { 1) Only focusing on challenges sexual minorities would } \\
\text { face } \\
\text { 2) The counselor hesitates intervention } \\
\text { 3) The counselor proceeds like an ordinary counseling } \\
\text { situation } \\
\text { 4) The counselor tries to make the client escape from } \\
\text { homosexuality } \\
\text { 5) It is hard for the counselor to empathize with clients }\end{array}$ & $\begin{array}{l}2 \text { (Variant) } \\
3 \text { (Variant) } \\
2 \text { (Variant) } \\
3 \text { (Variant) } \\
2 \text { (Variant) }\end{array}$ \\
\hline $\begin{array}{l}\text { 4. The usual attitude } \\
\text { towards the counselor's } \\
\text { sexual minorities }\end{array}$ & $\begin{array}{l}\text { 1) Since sexual minorities are socially rejected, the } \\
\text { counselor leaves the possibility of conversion } \\
\text { 2) The counselor recognizes sexual orientation conceptually } \\
\text { 3) The counselor regards homosexuality as attachment } \\
\text { issues rather than sexual ones }\end{array}$ & $\begin{array}{l}2 \text { (Variant) } \\
4 \text { (Variant) } \\
2 \text { (Variant) }\end{array}$ \\
\hline $\begin{array}{l}\text { 5. The influence of } \\
\text { counselor's attitude toward } \\
\text { sexual minority in } \\
\text { counseling }\end{array}$ & $\begin{array}{l}\text { 1) The counselor focuses on understanding and accepting } \\
\text { clients } \\
\begin{array}{l}\text { 2) The counselor can not understand and accept clients } \\
\text { 3) No impact on counseling }\end{array}\end{array}$ & $\begin{array}{l}3 \text { (Variant) } \\
2 \text { (Variant) } \\
3 \text { (Variant) }\end{array}$ \\
\hline $\begin{array}{l}\text { 6. Difficulties of sexual } \\
\text { minority counseling }\end{array}$ & $\begin{array}{l}\text { 1) It is hard for a counselor to get professional education } \\
\text { 2) It is hard for a counselor to empathize with clients due to } \\
\text { the limit of understanding } \\
\text { 3) It is hard to counsel after being overwhelmed by the } \\
\text { suffering of clients }\end{array}$ & $\begin{array}{l}3 \text { (Variant) } \\
5 \text { (Typical) } \\
4 \text { (Variant) }\end{array}$ \\
\hline $\begin{array}{l}\text { 7. Meaning of sexual } \\
\text { minority counseling }\end{array}$ & $\begin{array}{l}\text { 1) Widening the understanding of subjects as a counselor } \\
\text { 2) Worrisome counseling due to sexual prejudice } \\
\text { 3) The counseling which widens the understanding of } \\
\text { sexual minorities } \\
\text { 4) The counseling which is hard to find an answer due to } \\
\text { confusion } \\
\text { 5) The counseling which is not different from other ones } \\
\text { except for counseling subjects }\end{array}$ & $\begin{array}{l}2 \text { (Variant) } \\
2 \text { (Variant) } \\
3 \text { (Variant) } \\
3 \text { (Variant) } \\
2 \text { (Variant) }\end{array}$ \\
\hline $\begin{array}{l}\text { 8. The influence of } \\
\text { counselor's gender on } \\
\text { counseling }\end{array}$ & $\begin{array}{l}\text { 1) It is uncomfortable when the client views the counselor } \\
\text { as a sexual object } \\
\text { 2) The same-sex counselor can share the developmental } \\
\text { experience } \\
\text { 3) No impact on counseling }\end{array}$ & $\begin{array}{l}3 \text { (Variant) } \\
3 \text { (Variant) } \\
2 \text { (Variant) }\end{array}$ \\
\hline
\end{tabular}




\section{Discussion}

The discussion based on the study is as follows:

Firstly, "The process of finding out that the client is sexual minority" include a typical category such as "The gender identity of a client is exposed while counseling with a different subject". This correlates with the survey of the sexual minorities' counseling experience [3]: 48.9\% (387 persons) revealed their sexual orientation and gender identity while counseling and $66.4 \%$ (257 persons) naturally disclosed their gender identity.

What's meaningful in this study, even though it is variant, is that "A client discloses gender identity while signing up for an interview". This attitude would lay the foundation for sincere counseling. It is also noticeable that the client has a positive self-image, enough to "come out".

Secondly, "the psychological characteristics of the counselor after knowing that the client is sexual minority" include a typical response such as "Burden of counseling". The previous studies show that the accumulated practical experience in counseling does not lead to professional development [19] and the experience on taking a course in homosexuality affects the attitude on it rather than counseling careers [8]. Based on theses studies, the above responses reflect the reality of a counseling field where training or education on counseling sexual minorities is not sufficient.

Thirdly, when it comes to "Difficulties of sexual minority counseling", one typical response includes "It is hard for a counselor to empathize with clients due to the limit of understanding". With regard to "It is hard for a counselor to empathize with clients due to the limit of understanding", it correlates with various studies being conducted from the perspective of culturally oriented counseling. If therapists' culture is different from that of clients, they would have difficulties in applying existing theories, establishing relations between them and proceeding counseling [10]. It is in line with the study by [17], suggesting that if counselors turn a blind eye to clients' intrinsic cultural values or do not consider their cultural identity, the counselor would regard the clients as inferior ones.

The study aimed at figuring out difficulties counselors would face when counseling sexual minorities by looking at counselors' experience on counseling LGBT clients. The researcher can identify some issues as follows: Counselors in Korea intervene in sexual minorities inappropriately and have difficulties in empathizing with sexual minorities due to lack of understanding. In other words, counselors are ill-prepared for counseling sexual minorities. When it comes to counseling, the accumulation of practical experiences does not lead to the development of specific areas [19]. With this in mind, it is suggested that education and training on sexual minorities need to be provided to counselors in a systemic way.

\section{References}

[1] American Psychological Association, "Guidelines for psychological practice with lesbian, gay, and bisexual clients,” American Psychologist, vol.67, no.1, pp.10-42, (2012)

[2] B. J. Liddle. "Teaching of psychology," vol.24, no.1, pp.32-35

[3] Conversion therapy Elimination movement Network, Survey report on the counseling experience of sexual minorities, Seoul (2017)

[4] C. J. Gelso and R. E. Fassinger, “Annual review of psychology,” vol.41, no.1, pp.355-441

[5] C. J. Gelso and R. E. Fassinger, Journal of counseling psychology, vol.42, no.3, pp.356-364

[6] E. S. Spengler and D. J. Miller P. M., “Spengler," Psychotherapy, vol.53, no.3, pp.360-366, (2016) 
[7] F. A. Kelley, "Psychotherapy," vol.52, no.1, pp.113-118, (2015)

[8] G. M. Russell and J. S. Bohan, Journal of Gay and Lesbian Psychotherapy, vol.11, pp.59-76, (2007)

[9] J. E. Pachankis and M. R. Goldfried, Psychology of sexual orientation and gender diversity, vol.1, no.3, pp.45$58,(\mathbf{2 0 1 3})$

[10] J. M. Havenaar, Psychotherapy and Psychosomatics, vol.53, no.1-4, pp.8-13

[11] J. S. Whitman and M. P. Bidell, Journal of counseling and development, vol.92, no.2, pp.162-169, (2014)

[12] K. A. Barrett and B. T. McWhirter, Counselor Education and Supervision, vol.41, no.3, pp.219-232, (2002)

[13] K. Shelton and E. A. Delgado-Romero, Journal of counseling psychology, vol.58, no.2, pp.210-221, (2011)

[14] L. A. Burckell and M. R. Goldfried, division of psychotherapy, vol.43, no.1, pp.32-49, (2006)

[15] L. Garnets, K. A. and Hancock, S. D. Cochran, J. Goodchilds, and L. A. Peplau, American Psychologist, vol.46, no.9, pp.964-972

[16] Sa Rah Woo and Sung Kyung Yoo, The korean Journal of Counseling and Psychotherapy, vol.29, no.2, pp.311334, (2017)

[17] Tae Ho Kim, Multicultural Education Studies, vol.2, no.1, pp.54-76, (2009)

[18] Young Seok Seo and Jung Lim Lee, and Ju Hwan Cha, Korean Journal of Counseling and Psychotherapy, vol.18, no.1, pp.177-199, (2006)

[19] Yun Hee Go and Seong Hyeon Park, Korean Journal of Counseling and Psychotherapy, vol.26, no.4, pp. 805839, (2014)

\section{Authors}

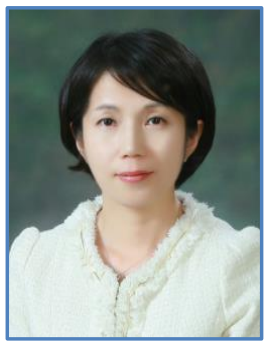

Author's profile.

Department Counseling Psychology Science, Tongmyong University Former Student Counseling Center Director, Tongmyong University 
Research on the Sexual Minority Counseling Experience of the Counselors

This page is empty by intention. 